
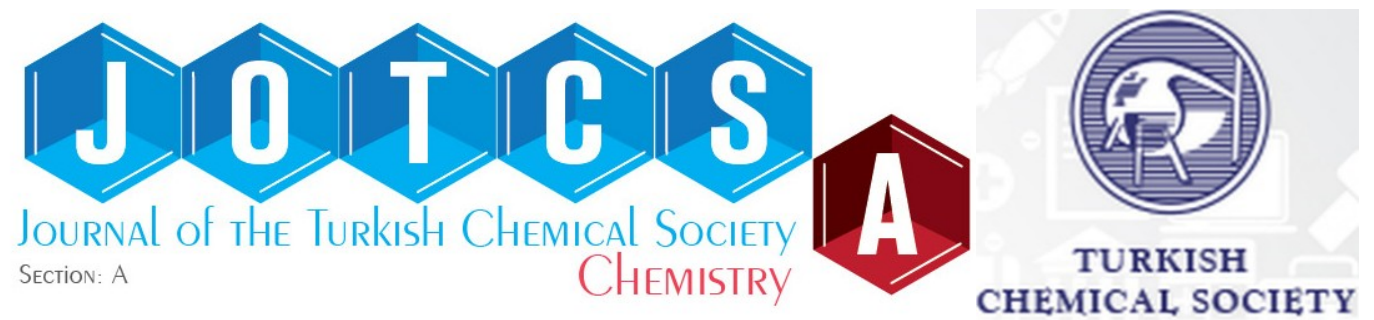

\title{
Antibiotic Susceptibility of Klebsiella pneumoniae Strains Isolated from Clinical Samples
}

\author{
Ahmet Ozan OZGEN ${ }^{1}$ D, Ozan Emre EYUPOGLU ${ }^{2}$ \\ ${ }^{1}$ İstanbul Medipol University, School of Pharmacy, 34810, Beykoz-Istanbul/ Turkey. \\ ${ }^{2}$ İstanbul Medipol University, School of Pharmacy, Biochemistry Department, 34810, Beykoz-Istanbul/ \\ Turkey.
}

Abstract: Antibiotic resistance in bacteria has become a worrying phenomenon in today's world. $K$. pneumoniae is a member of the Enterobacteriaceae family, which causes nosocomial infections as an opportunistic pathogen but inherently harboured as a part of the natural human microbiota. Carbapenem resistance of $K$. pneumoniae was a rare occurrence up to ten years ago, but in recent years many types of carbapenemase producing $K$. pneumoniae have become common. This retrospective study aims analysing susceptibility to various antibiotics, commonly used in treatment against $K$. pneumoniae strains isolated by using conventional methods from various infection sites. Antibiotic susceptibility tests were performed by using an automated system, the VITEK 2 Compact ${ }^{\circledR}$. In this study, 502 K. pneumoniae strains isolated from patients that treated at various services of a university hospital with 515-bed capacity were examined. When compared to the data available with studies of recent years in Turkey, especially in intensive care and inpatient services, the resistance of $K$. pneumoniae strains to antibiotics against most to carbapenems is rapidly increasing in the degree of high concern. Therefore, in all hospitals, antibiotic management policies should be implemented with a multidisciplinary approach.

Keywords: Enterobacteriaceae, Klebsiella pneumoniae, Drug Resistance, Bacterial, Retrospective Studies.

Submitted: October 20, 2019. Accepted: January 21, 2020.

Cite this: Ozgen A, Eyupoglu O. Antibiotic Susceptibility of Klebsiella pneumoniae Strains Isolated from Clinical Samples. JOTCSA. 2020; 7(1): 319-30.

DOI: https://doi.org/10.18596/jotcsa.635088.

*Corresponding author. E-mail: oeeyupoglu@medipol.edu.tr, Tel: +905385882070.

\section{INTRODUCTION}

Increasing resistance of bacteria is reported with each passing day. This global threat now requires the implementation of antibiotic management policies in all hospitals. In antibiotic management, there are packages of measures aimed at improving the quality of anti-infective therapy with regulations on dosage, method of administration, and duration of treatment. While the best possible treatment is configured for each patient individually, resistance development is minimised and costs are reduced considering public health (1). Many international guidelines have defined the structural requirements and basic strategies of antibiotic management (2). However, for example in the USA, there is a legal requirement for antibiotic management only since 2017. In Germany, the Infection Protection Law was amended in 2011 and necessary measures were taken to rationalise antibiotic consumption by hospitals (1). Also in Turkey, there is a legal penalty for antibiotic sale without a proper prescription only since 2017 (3).

The genus name of Klebsiella comes from the German scientist Edwin Klebs (1834-1913) who discovered them. It is a genus of bacteria that is 
often isolated from health facilities such as hospitals, nursing homes, and long-term treatment centers. The capsules of Klebsiella species are responsible for the mucoid appearance of bacterial colonies and the increased virulence of the microorganism in vivo. The most commonly isolated forms of these bacteria are Klebsiella oxytoca and Klebsiella pneumoniae, which cause nosocomial or community-acquired lobar pneumonia. Symptoms vary according to which part of the body is affected by the bacteria. Besides, these symptoms are the same regardless of which bacteria are the causes. For example, a Klebsiella-induced pneumonia patient and a patient suffering from pneumonia for another reason have the same symptoms as high fever, chills, chest pain, and difficulty of breathing (4).

Although $K$. pneumoniae is a bacterium that is resistant to many antibiotics, it is reported that $K$. pneumoniae has a natural resistance to ampicillin (4). Mostly cephalosporin and aminoglycoside antibiotics were chosen for the treatment of the infections caused by it, but $K$. pneumoniae isolates have developed resistance to cephalosporin by the production of extended-spectrum beta-lactamase (ESBL) enzymes and limited their use. Therefore, carbapenems are now preferred (5). With the introduction of carbapenems, resistance to these antibiotics has been reported too. Determining the appropriate treatment protocol for $K$. pneumoniae isolates and analysing the resistance status to prevent the development of resistance has become essential. High mortality rates have been seen in infections caused by $K$. pneumoniae strains resistant to carbapenems, especially septicemia. Most of these infections occur asymptomatic and the risk of comorbidity increases by previous surgeries, invasive devices and apparatuses and colonies commonly found in the body (6).

Although it is a rare phenotype in many geographical regions, carbapenem resistance of $K$. pneumoniae was first reported in 1983 . Then carbapenemase-producing $K$. pneumoniae (primarily in Greece) emerged and shown that they were producing Metallo-beta-lactamase (7). $K$. pneumoniae carbapenemase (KpC), a new family of enzymes, were first identified in the USA and caused epidemics, mainly in New York. Carbapenemase-producing Enterobacteriaceae members are susceptible only to polymyxins and tigecycline, so they pose a serious threat in hospitals and should be carefully monitored for carbapenem resistance (8).

In this study, $502 K$. pneumoniae isolates were examined which have been taken from the various clinical specimens. The isolates were transferred by medical personnel to the medical microbiology laboratory of a university hospital. Data were listed in the Microsoft Excel spreadsheets considering their susceptibility to antibiotics.

The aim of this retrospective study is analysing susceptibility to various antibiotics, commonly used in treatment, against $K$. pneumoniae strains isolated from various infection sites.

\section{MATERIALS AND METHODS}

Between 15.08.2017 and 10.11.2018, 502 microorganisms isolated from various regions of a university hospital were analysed retrospectively, considering patients' records. The study was approved by the ethics committee of İstanbul Medipol University.

\section{Collection of Isolates}

$K$. pneumoniae culture samples were provided to a university hospital's clinical microbiology laboratory from over 33 separate outpatient clinics and inpatient wards; MacConkey and blood agar cultivation was carried out by microbiologists and samples were incubated at $37^{\circ} \mathrm{C}$ for 17-24 hours. For the objectives of this research, only the cultures that tested positive for $K$. pneumoniae were included in the study. VITEK 2 Compact $\AA$ (Biomerieux, France), for the identification of species of isolated microorganisms, an automated bacterial identification system, and common conventional methods have been used.

\section{Susceptibility testing}

All susceptibility testing was performed in a clinical microbiology laboratory. Antibiotic susceptibility of the isolated strains to 16 antibiotics (Amikacin, Ampicillin, Ampicillin-Sulbactam, Imipenem, Meropenem, Levofloxacin, Ciprofloxacin, Fosfomycin, Nitrofurantoin, Amoxicillin-Clavulanic Acid, Piperacillin-Tazobactam, TrimethoprimSulfamethoxazole, Cefotaxime, Cefepime) were tested. The method was coordinated with VITEK 2 Compact $®$ (France, Biomerieux) automated antibiotic susceptibility testing system. Antimicrobial susceptibility of the isolates was examined by considering the recommendations of the European Antimicrobial Susceptibility Testing Committee (EUCAST) (9).

\section{Data organisation \& Statistical analysis}

The data was imported into Microsoft Excel (Microsoft, Inc., U.S.A.) spreadsheet file and allimportant patient identifiers were properly and securely discarded. The patients' data were classified according to type of clinic that they have been treated, nationality, sex, and age, microorganisms were classified according to the regions on patients they were colonised and antibiotic conditions were examined but not all 
antimicrobials were tested against each isolate. In the study group, patients between 10 and 60 years of age were included in the sample in order to avoid inconsistency in the analysis results of agerelated risk factors $(10,11)$. Descriptive statistical analysis of isolates was performed using the program Prism (software version 8.3.0 (538); GraphPad Software, LLC). T-tests (two-tailed), Chisquare (and Fisher's exact) tests were used to assess any significant differences among the groups. A probability value of $(P)<0.05$ was considered statistically significant.

\section{Comparison of materials and methods used in various studies}

While analysing, regional differences in antibiotic susceptibilities should be considered as a result of antibiotics that used commonly in that region. Risk factors that play a role in the development of infections such as microbiota status, age, sex, postoperative status, implant and chronic diseases of the patients should be considered. When necessary, these patients should be excluded from the study sample in order not to cause meaninglessness in the study and thus to reduce reliability $(10,11)$. Also, in studies involving large patient groups, separate studies should be conducted on the effects of risk factors on infection and bacterial resistance. Patients admitted to an institute as a tourist, especially in retrospective analysis, should be excluded from the research sampling when necessary, especially patients who cannot be treated in their own country because they are likely to have infections caused by bacteria with multiple drug resistance.

Many systems have been tried for continuous optimisation of treatment protocols, especially in the fight against nosocomial infections. However, in these studies, ones that placed the retrospective analysis method at the center, we encounter inconsistent results due to the risk factors mentioned. For example, systems such as the global anti-microbial resistance surveillance system (GLASS) have the disadvantage that they present too much data to a small staff to analyse, while not allowing them to validate results because of the distance from the environment where the data is obtained. The abundance of data distorts the study results and makes the analysis difficult. Singlecenter working groups should be formed and regional results should be combined (1).

Various programs (IBM SPSS, Stata, PSPP) are used for performing statistical analyses in clinical studies. Although statistical analyses can be performed manually by using the proper formulae for observed data (12). The program Prism was used in this study, and proper formulae were chosen according to literature sources that interest this study (13-15).

Clinical and statistical significance in medicine differs from each other. Statistical significance is making predictions about the population, which are based on the sample size of the patients, with clinical data gathered. So every statistically significant finding may not be clinically relevant, likewise for every clinically finding is subjected to the same situation. Considering this, various methods should be used to eliminate mistakes in clinical results and data should be organised in the best way possible for statistical analyses (16). For example, results obtained with automation systems such as VITEK 2 Compact and MALDI-TOF MS (e.g., carbapenem inactivation method (CIM) for Carbapenem resistance) should be provided manually at the center where the work is performed.

According to the data obtained in the centers where the studies are conducted, treatment protocols should be coordinated and implemented especially for the empirical treatment. The results of the studies should be compared according to the effectiveness of the treatments. Thus, another method can be obtained to validate the results of the studies (1).

\section{RESULTS}

The university hospital, which is the center of the study, accepts patients from many countries as shown in Figure 1. Thus, antibiotic resistance in different countries, Turkey is composed of comparisons with the data. 


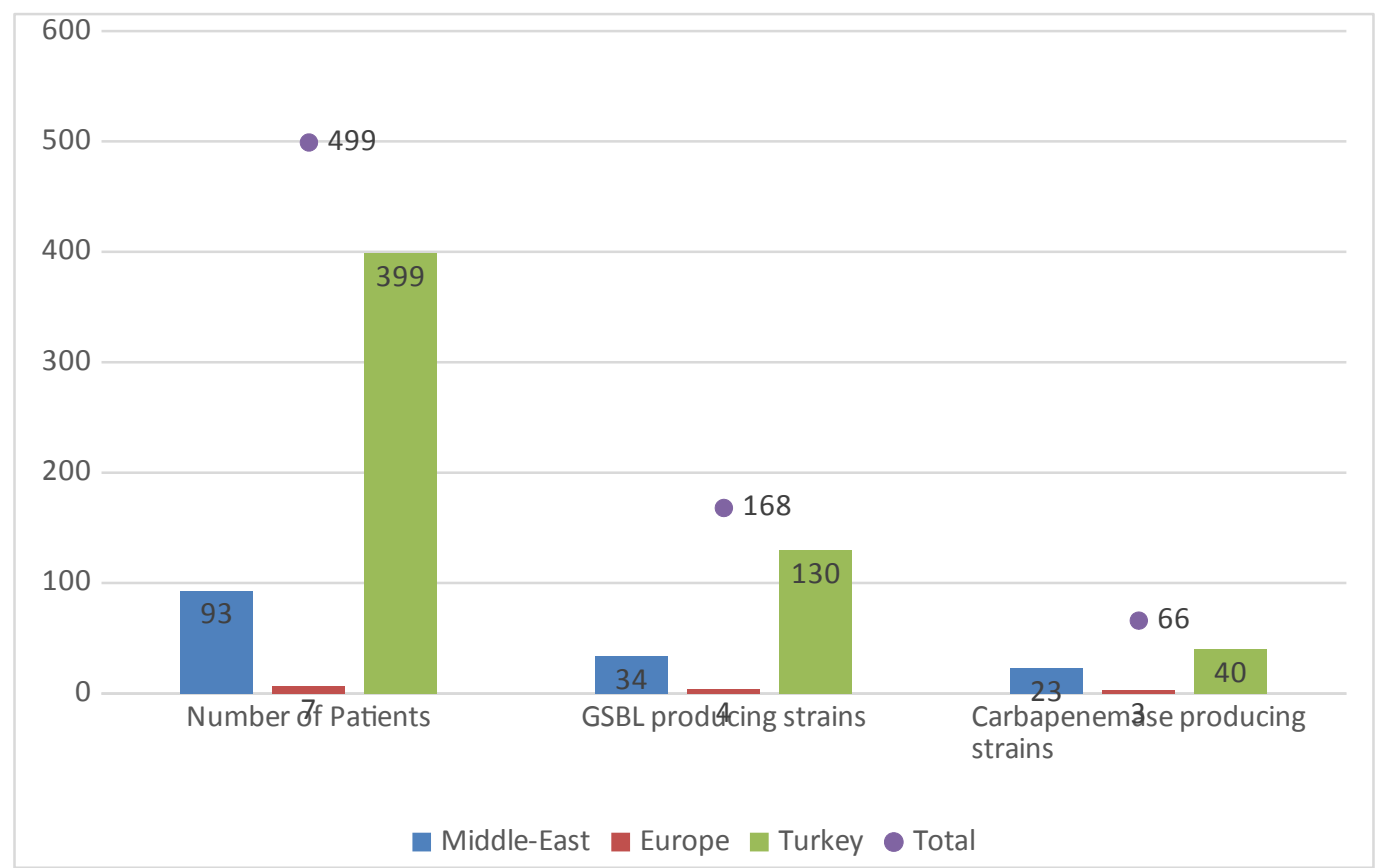

Figure 1: Patients sorted by their country.

As shown in Table 1 , there is only one strain that does not express any beta-lactamase and probably this result was obtained due to an error; because $K$. pneumoniae has a natural resistance to ampicillin (4). In $K$. pneumoniae, resistance to beta-lactam group antibiotics is of concern. In addition, Cefepim, a member of 4th generation cephalosporins, has superiority over 3rd generation Cefotaxime as expected. All ESBL positive strains are considered resistant to cefotaxime and other third-generation cephalosporins (17). Clinical use of carbapenems for Turkey is still effective in the treatment of $K$. pneumoniae infection. However, in order to prevent the development of resistance to this group of antibiotics in the future, particular attention should be paid to its use in the treatment of empirical therapy.

Table 1: Antibiotic susceptibility and total sample numbers of strains that were isolated ${ }^{\#}$

\begin{tabular}{|c|c|c|c|}
\hline Antibiotic & $\begin{array}{c}\text { Resistant } \\
\text { Strains }\end{array}$ & $\begin{array}{l}\text { Susceptible } \\
\text { strains }\end{array}$ & Total \\
\hline Amikacin & 34 & 383 & 417 \\
\hline Ampicillin* & 222 & 1 & 223 \\
\hline Ampicillin-Sulbactam & 121 & 101 & 222 \\
\hline Imipenem & 64 & 437 & 501 \\
\hline Meropenem & 88 & 414 & 502 \\
\hline Levofloxacin & 146 & 356 & 502 \\
\hline Ciprofloxacin & 168 & 334 & 502 \\
\hline Fosfomycin & 12 & 85 & 97 \\
\hline
\end{tabular}


Ozgen A, Eyupoglu O. JOTCSA. 2020; 7(1): 319-326.

RESEARCH ARTICLE

Nitrofurantoin

52

123

175

Amoxicillin-Clavulanic Acid

169

159

Piperacillin-Tazobactam

120

208

328

Trimethoprim-Sulfamethoxazole

160

168

328

Cefotaxime

224

193

417

Cefepime

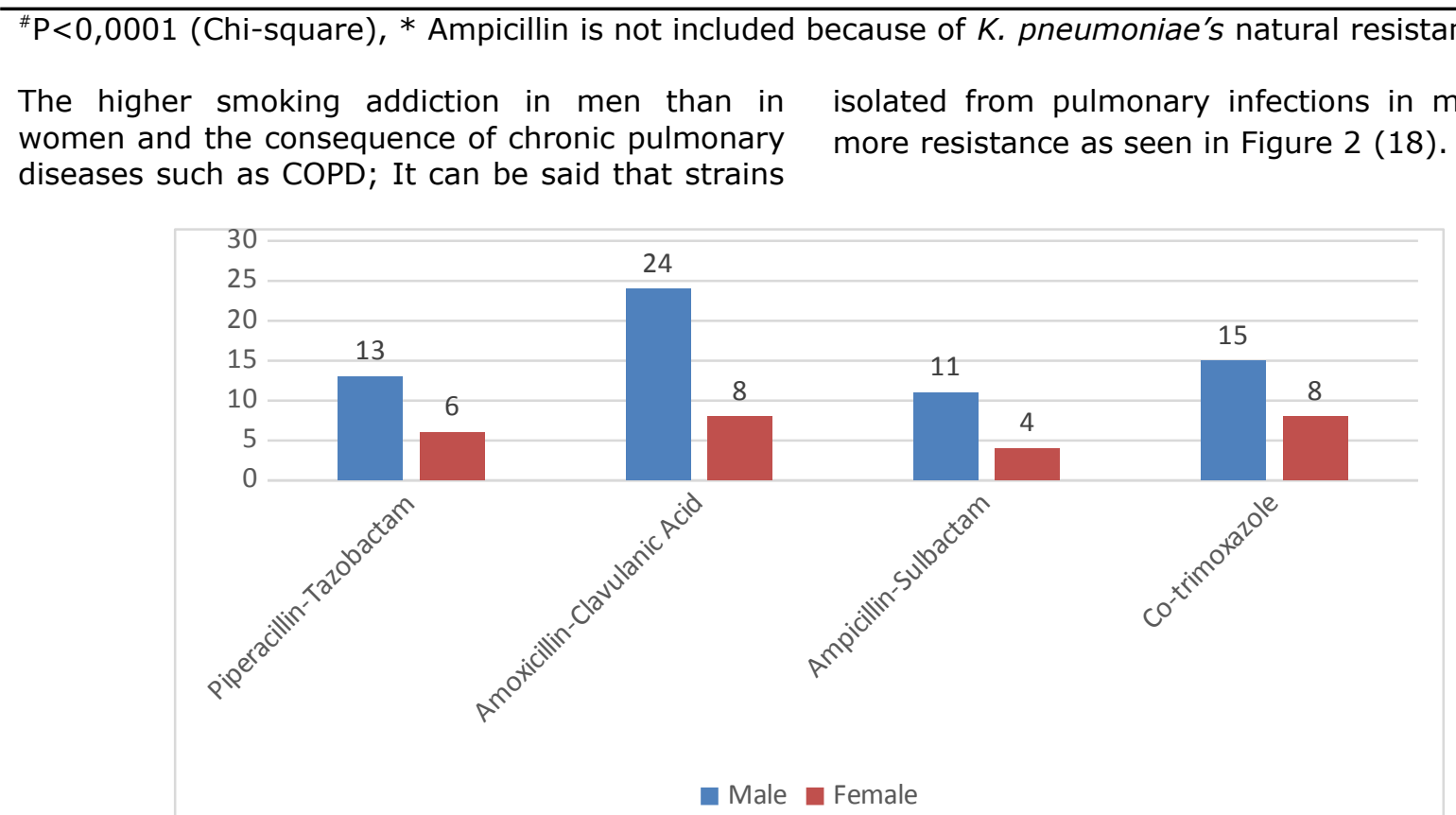

Figure 2: Gender distribution of antibiotic resistance of strains isolated from tracheal aspirate and bronchoalveolar lavage cultures, $\mathrm{P}=0.0261$ (T-test).

Women are more prone to urinary tract infections due to their biological structure (19). Therefore, women are exposed to bacterial profiles more resistant than males because they use more antibiotics against infection. Likewise, the distribution of efficacy of strains isolated from urinary tract infections against broad-spectrum fluoroquinolone antibiotics and phosphomycin was seen with high resistance in females (Figure 3 ). 


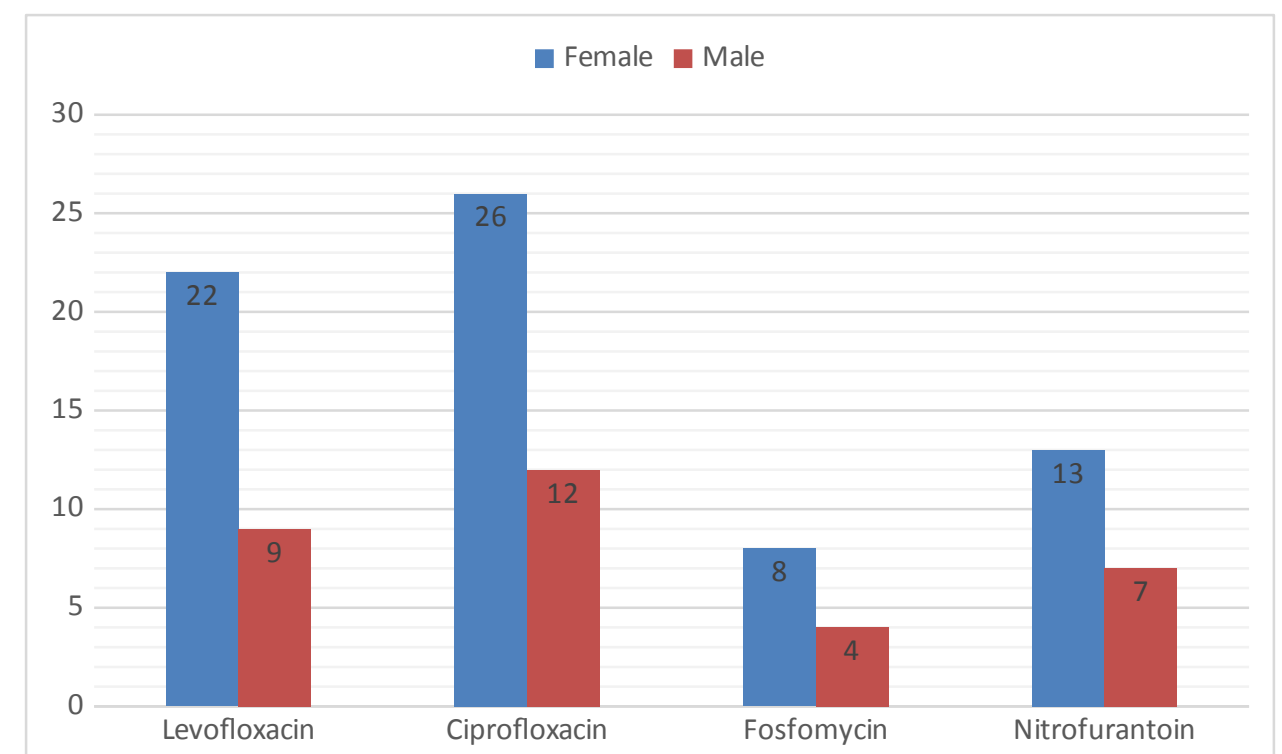

Figure 3: Resistance Distribution According to Gender in Urinary Tract Infections, $P=0.0341$ (T-test).

\section{DISCUSSION AND CONCLUSION}

Today, due to the unnecessary and widespread use of antibiotics, gram-negative rods with multidrug resistance are reported all over the world. In recent years, the treatment of strains that become hypervirulent by producing ESBL (oxacylanase, high-level AmpC Beta-Lactamase, Carbapenemase) has become a major problem due to the multiple resistance strains encountered in intensive care patients (20).

In a multi-center study conducted in our country, "Meropenem Yearly Susceptibility Test Information Collection"2007 data, $40.5 \%$ of $K$. pneumoniae strains were found to be ESBL positive (21). Different results have been observed in different regional studies conducted in our country. ESBL rates in $K$. pneumoniae strains were found to be $42 \%$ in another study and $74 \%$ in another study (22). According to another study conducted between 2007 and 2008, $41 \mathrm{~K}$. pneumoniae strains produced $24 \%$ ESBL (23). In this study, it can be stated that $33 \%$ of ESBL producing strains were detected.

Although it varies according to the region it is isolated, carbapenem resistance has started to be seen more frequently in our country. In a study that was conducted with 2903 strains isolated, Samasti et al. reported that carbapenem resistance of $K$. pneumoniae was found to be $3.13 \%$ (24). In another study conducted in 2014, they reported imipenem resistance to blood cultures as $47 \%$ and meropenem resistance as $45 \%$ (22). In this study, $13 \%$ of resistance was determined against carbapenems.
While analysing, regional differences in antibiotic conditions and the difference between the number of samples studied can be considered as the reason for the differences between susceptibility rates.

For further studies, susceptibility results should be provided by performing disc diffusion tests in the comparative analysis sections (e.g. analysing sexrelated factors on susceptibility), the zone radius should be used instead of positive/negative results. Besides, sample numbers should be equal. This will improve statistical significance.

Amoxicillin-Clavulanic Acid, in Turkey, is a common antibiotic used as an empirical treatment choice for community-acquired infections. Data gathered in this study shows that this choice of treatment is still partially effective against $K$. pneumoniae with a rate of $48.5 \%$.

Almost all of the studies in different geographies around the world show that the development of resistance to antibiotics is developing at an alarming rate. Therefore, to keep up with the bacteria in the fight against antibiotic resistance, sufficient personnel and resources need to be mobilised, but on the contrary, we see that some firms have terminated the budgets allocated for antibiotic research and even countries such as the USA are trying to implement national antibiotic management policies more recently (25).

ESBL production rates of E.coli, K. pneumoniae and other gram-negative enteric bacteria, which are expensive and difficult to treat, should be monitored by each center. In the treatment of infections preferred broad-spectrum beta-lactam 
antibiotics should be used with caution. Inpatients should be isolated and surveillance studies should be performed in hospital departments at risk.

Identification of organisms causing nosocomial infections, conducting in vitro antibiotic susceptibility tests and rational use of antibiotics may increase the chance of treatment success, prevent the spread of resistant nosocomial infections and reduce treatment costs. Therefore, antibiotic management policies should be implemented in all hospitals with a multidisciplinary approach.

\section{ACKNOWLEDGEMENT}

The authors would like to thank Dr. Betül GIRAY for her help in supplying research materials and Ph.D. Meltem Ezgi DURGUN for her help in statistical data analysis. We also appreciate the support from the management of Clinical Microbiology Laboratory, Medipol University Hospital.

\section{REFERENCES}

1. Sirijatuphat $R$, Sripanidkulchai $K$, Boonyasiri A, Rattanaumpawan $P$, Supapueng $O$, Kiratisin $P$, et al. Implementation of global antimicrobial resistance surveillance system (GLASS) in patients with bacteremia. PLOS ONE. 2018

Oca;13(1):e0190132.

2. Leung E, Weil DE, Raviglione M, Nakatani $H$. The WHO policy package to combat antimicrobial resistance. Bull World Health Organ. 2011 May;89:390-2.

3. Reçetesiz ilaç satılmıyor [Internet]. CNN Türk. [cited 2020 Jan 20]. Available from:

https://www.cnnturk.com/turkiye/recetesiz-ilacsatilmiyor

4. Murray PR. Aerobic Fermentative GramNegative Rods. In: Basic Medical Microbiology. Philadelphia, USA: Elsevier; 2018. p. 85-9.

5. Paterson DL. Resistance in gram-negative bacteria: Enterobacteriaceae. Am J Infect Control. 2006 Jun 1;34(5, Supplement):S20-8.

6. Bassetti M, Giacobbe DR, Giamarellou $H$, Viscoli C, Daikos GL, Dimopoulos G, et al. Management of KPC-producing Klebsiella pneumoniae infections. Clin Microbiol Infect. 2018 Feb;24(2):133-44.

7. Giakkoupi $P$, Xanthaki A, Kanelopoulou M, Vlahaki A, Miriagou V, Kontou S, et al. VIM-1 Metallo- -Lactamase-Producing Klebsiella pneumoniae Strains in Greek Hospitals. J Clin Microbiol. 2003 Aug 1;41(8):3893-6.

8. Pereira EC, Shaw KM, Vagnone PMS, Harper J, Lynfield R. A review of multidrug-resistant Enterobacteriaceae. Minn Med. 2011 Oct; 94(10):44-8.

9. Leclercq R, Cantón R, Brown DFJ, Giske CG, Heisig P, MacGowan AP, et al. EUCAST expert rules in antimicrobial susceptibility testing. Clin Microbiol Infect. 2013 Feb 1;19(2):141-60.

10. Liu C, Guo J. Hypervirulent Klebsiella pneumoniae (hypermucoviscous and aerobactin positive) infection over 6 years in the elderly in China: antimicrobial resistance patterns, molecular epidemiology and risk factor. Ann Clin Microbiol Antimicrob. 2019 Jan 21;18(1):4.

11. Dasgupta S, Das S, Chawan NS, Hazra A. Nosocomial infections in the intensive care unit: Incidence, risk factors, outcome and associated pathogens in a public tertiary teaching hospital of Eastern India. Indian J Crit Care Med Peer-Rev Off Publ Indian Soc Crit Care Med. 2015 Jan;19(1):14-20.

12. Taitt CR, Leski TA, Erwin DP, Odundo EA, Kipkemoi NC, Ndonye JN, et al. Antimicrobial resistance of Klebsiella pneumoniae stool isolates circulating in Kenya. Butaye $\mathrm{P}$, editor. PLOS ONE. 2017 Jun 2;12(6):e0178880.

13. Moghnieh R, Estaitieh N, Mugharbil A, Jisr T, Abdallah DI, Ziade F, et al. Third generation cephalosporin resistant Enterobacteriaceae and multidrug resistant gram-negative bacteria causing bacteremia in febrile neutropenia adult cancer patients in Lebanon, broad spectrum antibiotics use as a major risk factor, and correlation with poor prognosis. Front Cell Infect Microbiol [Internet]. 2015 Feb 12 [cited 2020 Jan 19];5. Available from:

http://journal.frontiersin.org/Article/10.3389/fcimb .2015.00011/abstract

14. Shao $Y$, Lu R, Yang $Y, X u$ Q, Wang B, Ye G. Antibiotic resistance of Helicobacter pylori to 16 antibiotics in clinical patients. J Clin Lab Anal. 2018 May;32(4):e22339.

15. Liu D-S, Wang $Y-H$, Zeng Z-R, Zhang Z-Y, Lu $\mathrm{H}, \mathrm{Xu} \mathrm{J}-\mathrm{M}$, et al. Primary antibiotic resistance of Helicobacter pylori in Chinese patients: a multiregion prospective 7 -year study. Clin Microbiol Infect. 2018 Jul;24(7):780.e5-780.e8.

16. Sainani KL. Clinical Versus Statistical Significance. PM\&R. 2012;4(6):442-5. 
17. Aykan ŞB, ÇiFtci İH. Türkiye'de İdrar Kültürlerinden İzole Edilen Escherichia coli Suşlarının Antibiyotiklere Direnç Durumu: Bir MetaAnaliz. :16.

18. Hardin $M$, Foreman $M$, Dransfield MT, Hansel $\mathrm{N}$, Han MK, Cho MH, et al. Sex-specific features of emphysema among current and former smokers with COPD. Eur Respir J. 2016 Jan 1;47(1):10412.

19. Fethers KA, Fairley CK, Hocking JS, Gurrin LC, Bradshaw CS. Sexual Risk Factors and Bacterial Vaginosis: A Systematic Review and Meta-Analysis. Clin Infect Dis. 2008 Dec 1;47(11):1426-35.

20. Balikçi H, Açikgöz ZC, Güvenman S, Çel N, Özdem B. Escherichia coli ve Klebsiella spp. İzolatlarında Plazmid Kaynaklı AmpC BetaLaktamaz Üretiminin Araştırılması. MİKROBİYOLOJİ Bül. :13.

21. Eraksoy $H$, Basustaoglu A, Korten V, Kurt $H$, Ozturk R, Ulusoy $S$, et al. Susceptibility of Bacterial Isolates From Turkey - A Report From the Meropenem Yearly Susceptibility Test Information Collection (MYSTIC) Program. J Chemother. 2007 Dec $1 ; 19(6): 650-7$.
22. Kahraman EP, Karakeçe E, Erdoğan F, Uluyurt H, Köroğlu M, Çiftci İH. Klebsiella pneumoniae izolatlarının antibiyotiklere direnç durumlarının değerlendirilmesi. Ortadoğu Tıp Derg. 2017 Mar 2;9(1):12-8.

23. Al-Muhtaseb M, Kaygusuz A. Kan kültürlerinden izole edilen Escherichia coli ve Klebsiella pneumoniae suşlarında genişletilmiş spektrumlu betalaktamaz (GSBL) sıklığı. ANKEM Dergi. 2008;22(4):175-82.

24. Samasti M, Koçoğlu ME, Davarci İ, Vahaboğlu $\mathrm{H}$, Çaşkurlu $\mathrm{H}$. Investigation of Carbapenemase Genes and Clonal Relationship in Carbapenem Resistant Klebsiella pneumoniae Strains. Bezmialem Sci. 2019 Jul 26;7(3):186-90.

25. Darby L. Antibiotic-Resistant Plagues Are Coming and We're Wildly Unprepared [Internet]. [cited 2019 Oct 20]. Available from: https://www.gq.com/story/antibiotic-resistantplagues-are-coming 


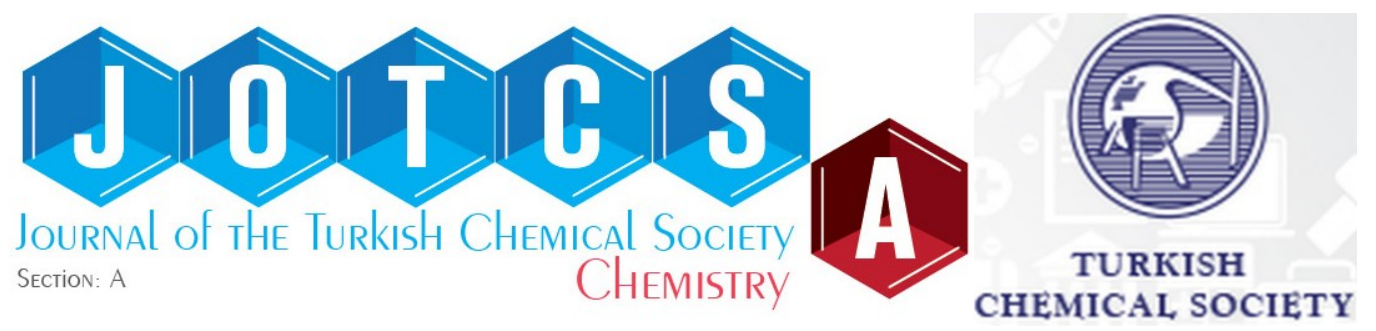

Antibiotic Susceptibility of Klebsiella pneumoniae Strains Isolated from Clinical Samples

\section{Ahmet Ozan OZGeN ${ }^{1}$, Ozan Emre EYUPOGLU ${ }^{2}$}

${ }^{1}$ İstanbul Medipol University, School of Pharmacy, 34810, Beykoz-Istanbul/ Turkey

2İstanbul Medipol University, School of Pharmacy, Biochemistry Department, 34810, Beykoz-Istanbul/ Turkey

\section{SUPPLEMENTARY INFORMATION}

1) Ethical council's decision

2) Decision form 
T.C.

İSTANBUL MEDIPPOL ÜNIVERSITESI

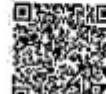

E-Imsalider Girişimsel OImayan Klinik Araştırmalar Etik Kurulu Başkanı̆ı̆ı

Say1 : 10840098-604.01.01-E.53649

Konu : Etik Kurulu Karan

\title{
Sayn Ahmet Ozan ÖZGEN
}

\begin{abstract}
Ûniversitemiz Girişimsel Olmayan Klinik Araştırmalar Etik Kuruluna yapmiş olduğunuz "Klinik örneklerden izole edilen. Klebsiella pneumoniae suşlarının antibiyotik duyarlılıkları" isimli başvurunuz incelenmiş olup etik kurulu kararı ekte sunulmuștur.

Bilgilerinize rica ederim.
\end{abstract}

Prof. Dr. Hanefi ÖZBEK

Girişimsel Olmayan Klinik Araștırmalar Etik Kurulu Başkanı

Ek:

-Karar Formu (2 sayfa)

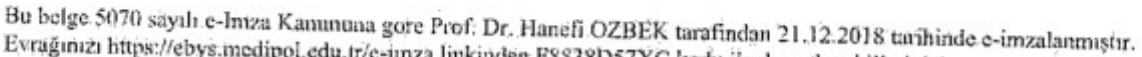
Evrağınıż htţ̧://ebys.medipol.edu.trie-inza linkinden F8838D57XC kodu ile dogrulayabilirsiniz. 
ISTANBUL MEDIPOL ONNIVERSITESI

GIRIŞiMSEL OLMAYAN KLINIIK ARASSTIRMALAR

ETIK KURULU KARAR FORMU

\begin{tabular}{|c|c|c|c|c|c|}
\hline \multirow{6}{*}{ 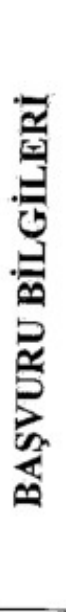 } & ARAŞTIRMANIN AÇIK ADI & \multicolumn{4}{|c|}{$\begin{array}{l}\text { Klinik örneklerden izole edilen Klebsiella pneumoniae } \\
\text { suşlarının antibiyotik duyarlllkklar! }\end{array}$} \\
\hline & $\begin{array}{c}\text { KOORDINATÖR/SORUMLU } \\
\text { ARASTIRMACI } \\
\text { UNVANI/ADI/SOYADI }\end{array}$ & \multicolumn{4}{|c|}{ Ahmet Ozan ÖZGEN } \\
\hline & $\begin{array}{l}\text { KOORDINATÖH/SORUMLU } \\
\text { ARASTIRMACININ } \\
\text { UZMANLIK ALANI }\end{array}$ & \multicolumn{4}{|l|}{ Ö̌renci } \\
\hline & $\begin{array}{c}\text { KOORDINATÖRUSORUMLU } \\
\text { ARASTIRMACININ } \\
\text { BULUNDUĞU MERKEZ }\end{array}$ & \multicolumn{4}{|l|}{ Istanbul } \\
\hline & DESTEKLEYICI & \multicolumn{4}{|l|}{$\cdot$} \\
\hline & $\begin{array}{l}\text { ARAȘTIRMAYA KATILAN } \\
\text { MERKEZLER } \\
\end{array}$ & $\begin{array}{c}\text { TEK MERKEZ } \\
\square\end{array}$ & 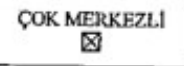 & $\underset{\otimes}{\text { ULUSAL }}$ & $\begin{array}{c}\text { ULUSLARARASI } \\
\square\end{array}$ \\
\hline
\end{tabular}


ISTANBUL MEDIPOL ÔNIVERSITESI GIRIŞiMSEL OLMAYAN KLINITK ARAŞTIRMALAR

ETIK KURULU KARAR FORMU

\begin{tabular}{|c|c|c|c|c|c|c|}
\hline \multirow{3}{*}{ 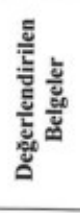 } & Belge Adı & Tarihi & $\begin{array}{c}\text { Versiyon } \\
\text { Numarası }\end{array}$ & \multicolumn{3}{|c|}{ Dili } \\
\hline & ARASTIRMA PROTOKOLO/PLANI & & & Türkçe $\square$ & Ingilizce $\square$ & Diger $\square$ \\
\hline & $\begin{array}{l}\text { BLLGILENDIRILMIS GONOLLO OLUR } \\
\text { FORMU }\end{array}$ & & & Türkçe $\unrhd$ & Ingilizce $\square$ & Diger $\square$ \\
\hline & Karar No: 764 & \multicolumn{5}{|c|}{ Tarih: 19/12/2018 } \\
\hline 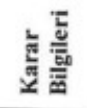 & \multicolumn{6}{|c|}{$\begin{array}{l}\text { Yukarıda bilgileri verilen Girişimsel Olmayan Klinik Araştırmalar Etik Kurulu başvuru dosyassı ile ilgili } \\
\text { belgeler araştırmanın gerekçe, amaç, yaklaşım ve yöntemleri dikkate alınarak incelenmiş ve araştırmanın } \\
\text { etik ve bilimsel yönden uygun olduğuna "oybirliği" ile karar verilmiştir. }\end{array}$} \\
\hline
\end{tabular}

\begin{tabular}{|l|l|}
\hline \multicolumn{2}{|c|}{ ISTANBUL MEDiPOL ÖNIVERSITESI GIRIȘiMSEL OLMAYAN KLINIK ARAŞTIRMALAR ETIK KURULU } \\
\hline BAȘKANIN UNVANI / ADI / SOYADI & Prof. Dr. Hanefi ÖZBEK \\
\hline
\end{tabular}

\begin{tabular}{|c|c|c|c|c|c|c|c|c|c|}
\hline \multirow{2}{*}{$\begin{array}{l}\text { Unvanu/Adu/Soyadı } \\
\text { Prof. Dr. Şeref } \\
\text { DEMIRAYAK }\end{array}$} & \multirow{2}{*}{$\begin{array}{c}\text { Uzmanlık Alanı } \\
\text { Eczacılık }\end{array}$} & \multirow{2}{*}{\begin{tabular}{l}
\multicolumn{1}{c}{ Kurumu } \\
Istanbul \\
Medipol \\
Ôniversitesi
\end{tabular}} & \multicolumn{2}{|c|}{ Cinsiyet } & \multicolumn{2}{|c|}{$\begin{array}{c}\text { Arastarma ile } \\
\text { ilighi }\end{array}$} & \multicolumn{2}{|c|}{ Kathan* } & \multirow[t]{2}{*}{ Imza } \\
\hline & & & $\mathrm{E} \otimes$ & $k \square$ & $\mathrm{E} \square$ & н $\bigotimes$ & $\mathrm{E} \otimes$ & н $\square$ & \\
\hline Prof. Dr. Hanefi ÖZBEK & Farmakoloji & $\begin{array}{l}\text { Istanbul } \\
\text { Medipol } \\
\text { Oniversitesi }\end{array}$ & $\mathrm{E} \otimes$ & $\mathrm{k} \square$ & $\mathrm{E} \square$ & н $\bigotimes$ & $\mathrm{E} \otimes$ & н $\square$ & \\
\hline Doç. Dr. Ilknur KESKİN & $\begin{array}{l}\text { Histoloji ve } \\
\text { Embriyoloji }\end{array}$ & $\begin{array}{l}\text { Istanbul } \\
\text { Medipol } \\
\text { Oniversitesi }\end{array}$ & E $\square$ & $\mathrm{k} \otimes$ & $\mathrm{E} \square$ & н $\bigotimes$ & $\mathrm{E} \otimes$ & н $\square$ & \\
\hline $\begin{array}{l}\text { Dr. Ögrr. Oyesi Devrim } \\
\text { TARAKCI }\end{array}$ & Ergoterapi & $\begin{array}{l}\text { Istanbul } \\
\text { Medipol } \\
\text { Oniversitesi }\end{array}$ & $\mathrm{E} \otimes$ & к $\square$ & $\mathrm{E} \square$ & н $\bigotimes$ & $\mathrm{E} \square$ & $\mathrm{H} \otimes$ & \\
\hline $\begin{array}{l}\text { Dr. Ögr. Ôyesi Sibel } \\
\text { DOGAN }\end{array}$ & Psiko-onkoloji & $\begin{array}{l}\text { Istanbul } \\
\text { Medipol } \\
\text { Oniversitesi }\end{array}$ & $\mathrm{E} \square$ & $\mathrm{k} \otimes$ & $\mathrm{E} \square$ & н $\bigotimes$ & $\mathrm{E} \otimes$ & н $\square$ & \\
\hline $\begin{array}{l}\text { Dr. Ögr. Oyesi Mehmet } \\
\text { Hikmet ƠÇIŞIK }\end{array}$ & Biyoteknoloji & $\begin{array}{l}\text { Istanbul } \\
\text { Medipol } \\
\text { Oniversitesi }\end{array}$ & $\mathrm{E} \otimes$ & $\kappa \square$ & $\mathrm{E} \square$ & н区 & $\mathrm{E} \otimes$ & н $\square$ & \\
\hline $\begin{array}{c}\text { Dr. Ōgr. Ôyesi Keziban } \\
\text { OLCAY }\end{array}$ & Endodonti & $\begin{array}{l}\text { İstanbul } \\
\text { Medipol } \\
\text { Ôniversitesi }\end{array}$ & $\mathrm{E} \square$ & $\kappa \otimes$ & $\mathrm{E} \square$ & н $\bigotimes$ & $\mathrm{E} \otimes$ & н $\square$ & \\
\hline
\end{tabular}

- Toplantida Bulunma 